\title{
Airborne Transmission of Avian Origin H9N2 Influenza A Vi- ruses
}

\author{
C. Joaquín Cáceres ${ }^{1}$, Daniela S. Rajao ${ }^{1 *}$ and Daniel R. Perez ${ }^{1 *}$
}

\author{
${ }^{1}$ Department of Population Health, College of Veterinary Medicine, University of Georgia, Athens, 30602, GA, \\ USA. \\ * Correspondence: authors: \\ Department of Population Health, College of Veterinary Medicine, University of Georgia. \\ 953 College Station Road, Athens, GA 30602. \\ E-mail: daniela.rajao@uga.edu; dperez1@uga.edu. Telephone: 706-542-3689; 706-542-5506
}

\begin{abstract}
Influenza A viruses (IAV) are widespread viruses affecting avian and mammalian species worldwide. Outbreaks of IAV in poultry are usually associated with substantial morbidity and mortality, significantly affecting the poultry industry and food security. IAVs from avian species can be transmitted to mammals including humans and, thus, they are of inherent pandemic concern. Most of the efforts to understand the pathogenicity and transmission of avian origin IAVs have been focused on $\mathrm{H} 5$ and $\mathrm{H} 7$ subtypes due to their highly pathogenic phenotype in poultry. However, IAV of the $\mathrm{H} 9$ subtype that circulate endemically in poultry flocks in some regions of the world have also been associated with cases of zoonotic infections. As a result, the World Health Organization includes avian origin H9N2 IAV among the top in the list of IAVs of pandemic concern. In this review, we discuss the interspecies transmission of H9N2 between avian and mammalian species and the molecular factors that are thought relevant for this spillover. Additionally, we discuss factors that have been associated with the ability of these viruses to transmit through the respiratory route in mammalian species.
\end{abstract}

Keywords: H9N2; influenza; aerosol; interspecies; zoonotic; pandemic

\section{INTRODUCTION}

Influenza A viruses (IAV) are members of the family Orthomyxoviridae with a segmented RNA genome of negative polarity. IAV are divided into subtypes by the combination of the surface proteins, the hemagglutinin (HA, H1-H18) and the neuraminidase (NA, N1-N11) (Krammer et al. 2018). The natural hosts of IAV are wild aquatic birds, particularly waterfowl and seabirds, in which most of the IAV subtypes have been described (Carnaccini and Perez 2020, Peacock et al. 2019). From the wild bird reservoir, IAVs sporadically spill over to domestic poultry species causing disease outbreaks and become endemic. This has been the case for some H5Nx, H7Nx or H9N2 IAV viruses (Banet-Noach et al. 2007, Berhane et al. 2009, Choi et al. 2004, Monne et al. 2013, Morales et al. 2009, Sonnberg et al. 2012). IAVs of avian origin are classified in highly pathogenic avian influenza viruses (HPAIVs) and low pathogenic avian influenza viruses (LPAIVs) based on the pathotype in chickens and/or the presence of a polybasic cleavage site in the HA (Alexander 2003). The HA's polybasic cleavage site of HPAIVs allows for processing of the HA by endogenous cellular furin-like proteases, leading to systemic infections and increased pathogenicity. In contrast, LPAIVs contain no more than a tri-basic cleavage site in the HA, making them dependent on extracellular trypsin-like proteases for processing, 
limiting infections to sites where such enzymes are abundant (e.g., respiratory and/or gastrointestinal systems) (Alexander 2003, Organization 2005, Service). Only viruses of the $\mathrm{H} 5$ or $\mathrm{H} 7$ subtype have been associated to the HPAI pathotype.

\section{H9N2 AVIAN INFLUENZA VIRUSES}

IAVs of the H9N2 subtype are widespread in different species of wild waterfowl, shorebirds, and poultry, such as chickens, turkeys, quails, among others (Hassan et al. 2020, Jackwood and Stallknecht 2007, Reid et al. 2016, Swieton et al. 2018, Swieton et al. 2020, Xu et al. 2007). H9N2 IAVs are the most prevalent LPAIVs, enzootic in poultry in parts of Asia, the Middle East, and Africa (reviewed in (Carnaccini and Perez 2020)). IAVs H9N2 were first isolated from turkeys in Wisconsin, USA in 1966 (Homme and Easterday 1970), with subsequent sporadic detections in poultry in the US. H9N2 viruses were first isolated from healthy ducks from farms and live poultry markets in Hong Kong between 1975-1985 (Markwell and Shortridge 1982, Shortridge 1992). In 1988, the first evidence of H9N2 infection in poultry in Asia was reported after a respiratory outbreak in quails (Perez et al. 2003). Currently, IAVs H9N2 are widespread in poultry species around the world with particularly high prevalence in Asia (Banet-Noach et al. 2007, Cameron et al. 2000, Guan et al. 2000).

H9N2 IAV infections are usually mild. However, significant economic losses are associated with H9N2 infections because of delayed growth and lower egg production. Studies have shown that H9N2 virus replication in the oviduct results in poor eggshell quality and deterioration of eggshell (Bonfante et al. 2018, Qi et al. 2016, Sid et al. 2017). H9N2 infections in poultry are also associated with secondary respiratory pathogens, such as infectious bronchitis virus and Mycoplasma gallisepticum, which can lead to high mortality (Arafat et al. 2020, Awuni et al. 2019, Bonfante et al. 2018, Chu et al. 2017, Jakhesara et al. 2014, Nili and Asasi 2002, Smietanka et al. 2014, Wang et al. 2015).

Phylogenetic analyses of the H9 HA have classified the H9 into two lineages: the American and Eurasian lineages, which are further divided into four sub-lineages (h9.1 to h9.4)(Carnaccini and Perez 2020). Strains in the h9.1 sub-lineage are present mostly in wild birds in America, those from the h9.2 sub-lineage circulate in Korean poultry and wild birds in Eurasia, whereas those from the h9.3 sub-lineage (BJ94-like strains) are present in poultry in China. Viruses from the h9.4 sub-lineage (G1-like) are endemic in poultry in the Middle East, India, Egypt and Africa (extensively reviewed in (Carnaccini and Perez 2020)). Antigenic characterization of the HA of $\mathrm{H} 9$ viruses showed that these viruses, like other IAVs, show an immunodominance mediated by the globular head of the HA. Interestingly, the HA of the H9 subtype lack the 130 lateral loop that forms the antigenic site A in other subtypes, such as H5 or H3 HAs (Li et al. 2020, Wiley et al. 1981). Such feature results in two antigenic sites that overlap, designated site I and site II (Kaverin et al. 2004). More recent work showed the presence of alternative non-overlapping antigenic sites designated H9-A and H9-B, where H9-A shares amino acids with site I and is immunodominant in comparison to H9-B (Peacock et al. 2016). Genetic and antigenic differences are observed within lineages circulating in specific regions, and antigenic drift has been observed in regions where these viruses are endemic, such as China and Egypt (Adel et al. 2017, Wei et al. 2016).

Of great significance, H9N2 IAV viruses have contributed the internal gene segments to more deadly zoonotic strains such as H5N1/N6, H7N9, and H10N8/N3 that have been implicated in human infections and loss of life (Guan et al. 1999, Lam et al. 2013, Pu et al. 2021, Wang et al. 2021). In addition, H9N2 IAVs are zoonotic viruses themselves and have also been reported in other mammalian species such as swine, dogs, horses, and mink. In humans, H9N2 IAV infections have presented with mild influenza-like symptoms such as respiratory symptoms, cough, fever, runny nose, sore throat, and headache (Butt et al. 2005, Cong et al. 2008, Jallow et al. 2020, Peiris et al. 1999, Sun et al. 2021). However, such mild infections could be the prelude to the selection of more virulent strains with the 
capacity of transmit in humans more efficiently. Therefore, understanding the factors required for efficient transmission of H9N2 viruses in mammalian species is essential for adequate pandemic preparedness. In this review, we will discuss the transmission of H9N2 IAV in mammalian species providing an overview of the molecular features that may facilitate the respiratory transmission of these viruses, focusing mostly on the collective findings from our group.

\section{MOLECULAR MECHANISMS ASSOCIATED WITH INTERSPECIES TRANSMISSION OF IAVs}

Several molecular signatures have been associated with host range restriction and species jump of IAV in mammalian species. Particularly, the segments encoding the HA and the polymerase complex play a major role in the host range and adaptation of IAVs (Van Hoeven et al. 2009). The HA is responsible for receptor-binding to the host cells and the fusion between the endosomal membranes and viral envelope (Das et al. 2018, Edinger et al. 2014). An important barrier in the avian to human transmission of IAV is the different binding specificities of IAV to terminal sialic acid present on the glycan receptors on the host cell surface. IAVs of avian origin bind preferentially to $\alpha 2,3$-linked sialic acids $(\alpha 2,3 S A)$ and those from human origin viruses bind preferentially to $\alpha 2,6$-linked sialic acids ( $\alpha 2,6 \mathrm{SA}$ ) (Xiong et al. 2014). The $\alpha 2,3 \mathrm{SA}$ versus $\alpha 2,6 \mathrm{SA}$ preference is mediated by key residues located in the HA; specifically, positions 226 and 228 (H3-numbering used throughout the text) are critical for receptor specificity in H3 and H9 viruses (Fig 1A) (Obadan et al. 2019, Rogers et al. 1983, Wan and Perez 2007). H9N2 IAVs endemic in poultry have variations at position 226 with most isolates carrying leucine (L) and others glutamine (Q) (Fig 1B). At position 228, glycine (G) is present in almost all H9 isolates detected to date. Indeed, an analysis of more than 2,500 H9 isolates from avian and mammalian hosts showed a switch in the 226 position over the years, with the majority of H9N2 IAV isolates carrying Q226 before 2000 while newer H9N2 IAV isolates revealed high prevalence of 226L (Sun et al. 2020). Viruses with the Q226/G228 combination present dual binding or $\alpha 2,3 S A$ avian-like preference. A single Q226L mutation produces a switch to $\alpha 2,6 S A$ human-like preference (Vines et al. 1998, Wan et al. 2008). Consistent with these observations, most H9N2 IAVs identified in poultry farms and live bird markets exhibit binding to human-like receptors (Matrosovich et al. 2001, Zou et al. 2019). More importantly, most H9N2 viruses isolated from mammalian species, including human isolates, show the L226/G228 combination (Fig 1B). Interestingly when swine sequences are analyzed, there is an even distribution between isolates carrying Q226 or L226 (Fig 1B). In addition, other amino acid signatures can modulate and/or enhance binding of H9 HAs to terminal $\alpha 2,6 \mathrm{SAs}$, such as the mutation from isoleucine (I) to threonine (T) at position 155 (Li et al. 2014) or the presence of a valine (V) at position 190 (Teng et al. 2016). The modulation of receptor binding preference by V190 is reminiscent of similar effects in HAs of the H1 subtype (Matrosovich et al. 2000). The presence of Q227 in combination with either aspartic acid (D) or glutamic acid (E) at position 190 favors binding $\alpha 2,6$ SAs receptors. 


\section{A. Position 226 binding preference}

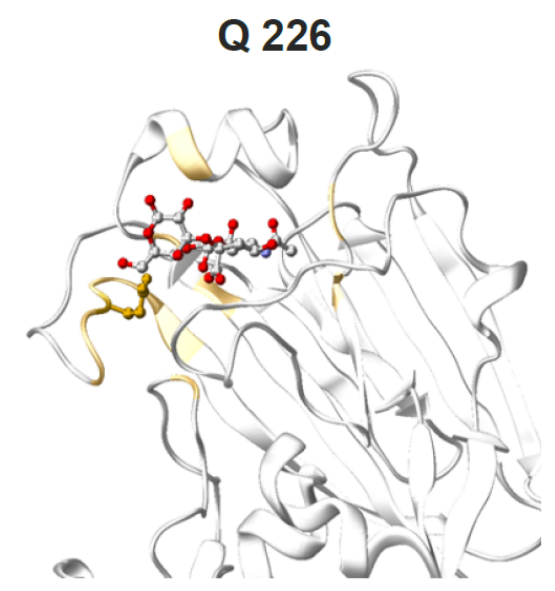

$\alpha 2,3$-linked sialic acid preference
L 226

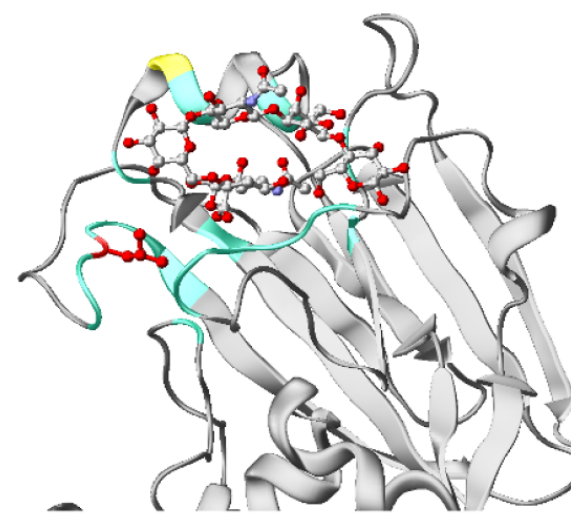

a2,6-linked sialic acid preference

\section{B. Number of variants in Position 226 in natural isolates}

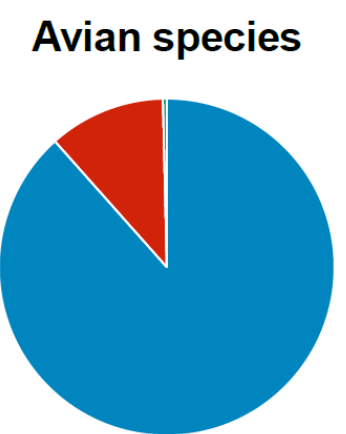

$n=6,203$

$\mathrm{L}(88.4 \%)$

$\mathrm{Q}(11.2 \%)$

Other $(0.4 \%)$

M, N, R, H, I, F, P

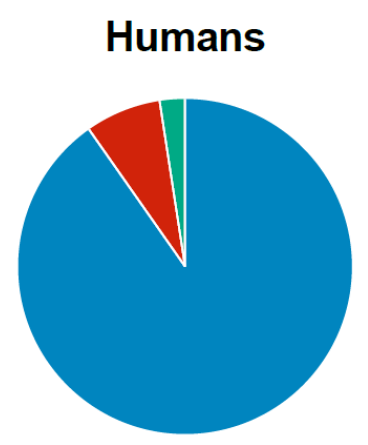

$\mathrm{n}=\mathbf{4 1}$

$\mathrm{L}(90.2 \%)$

$\mathrm{Q}(7.3 \%)$

$\mathrm{M}(2.5 \%)$

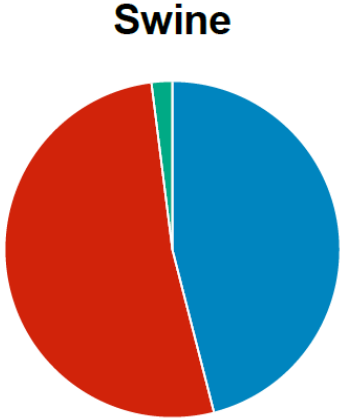

$\mathrm{n}=\mathbf{5 0}$

$\mathrm{L}(46 \%)$

$\mathrm{Q}(52 \%)$

$\mathrm{M}(2 \%)$
Other Mammals

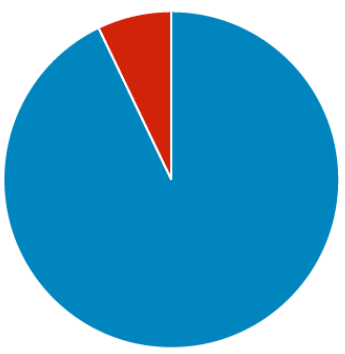

$n=14$

$\mathrm{L}(92.9 \%)$

Q $Q(7.1 \%)$

\section{Transmission of field H9N2 viruses with L226 x Q226 in ferrets}

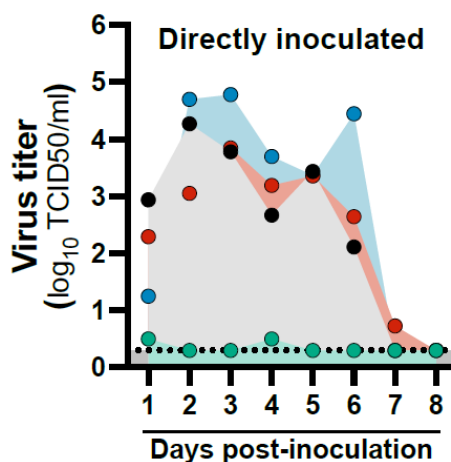

Direct contact

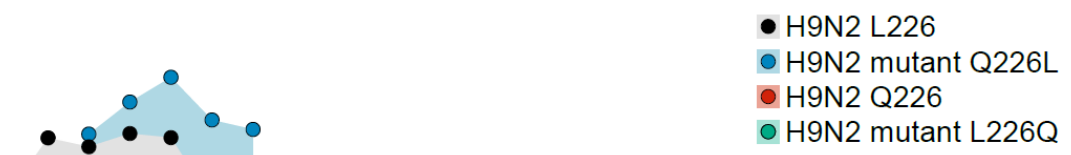

Figure 1. Impact of position 226 in the H9 of H9N2 IAV viruses. (A) The 3D molecular structure of the H9 HA glycoprotein globular head from A/Guinea Fowl/Hong Kong/WF10/99 (WF10) with glutamine (Q) or leucine (L) in position 226. The sialic acid binding is shown in each case. Structure constructed using the iTASSER structure prediction tool (Yang et al. 2015). (B) The different residues in position 226 of the H9 were analyzed from H9N2 IAV isolated for avian species, humans, swine, and other mammals (canine, equine, and mink). Full H9 sequences were downloaded from the global initiating on sharing all influenza data (GISAID). Sequence analyses were performed using Geneious Prime 2020.2.4 
(https://www.geneious.com). (C) Summary of the replication, transmission by direct contact or airborne transmission in ferrets inoculated with H9N2 IAV viruses carrying L226 (H9N2 L226) or Q226 (H9N2 Q226) in the H9. Data for replication and transmission of mutant viruses with H9 Q226L (H9 mutant Q226L) or H9 L226Q (H9N2 mutant L226Q) are also shown. Results compiled from (Wan et al. 2008).

The viral polymerase subunits PB1, PB2, and PA, can also contribute to the adaptation of IAV of avian origin to mammalian hosts. Of interest, the change from $E$ to lysine $(\mathrm{K})$ in position 627 (E627K) in PB2 is a major determinant of host restriction. This has been the predominant host adaptation marker identified in human cases of H5N1 and H7N9 infections (Li et al. 2004, Wang et al. 2014). A higher frequency of PB2 K627 is observed in H9N2 viruses isolated from mammalian hosts in comparison to avian counterparts. Interestingly, more than $20 \%$ of H9N2 viruses from human cases possess the PB2 V627 signature, which was also observed in transmission experiments between avian and mammalian species (Luk et al. 2015). It is worth noting that position 627 modulates the optimal temperature for virus replication. The PB2 K627 is associated with increased polymerase activity and replication at $33-37^{\circ} \mathrm{C}$, an attribute necessary for replication in the human respiratory tract. In contrast, the PB2 E627 mutation allows for optimal replication at $39-41^{\circ} \mathrm{C}$, consistent with the body temperature of most bird species. Furthermore, the PB2 E627K have also been observed 3 days post-inoculation in mice when a duck-origin H9N2 IAV virus is previously serially passaged in chickens and quails, suggesting that the adaptation to land-based birds can also contribute to a faster acquisition of mutations that favor replication in mammals (Hossain et al. 2008), which suggest that PB2 E627K is a respiratory tract adaptation rather than a mammalian adaptation.

The PB2 A588V mutation is also potentially involved in mammalian adaptation. H9N2 IAVs carrying the PB2 V588 signature show enhanced virulence in mice (Xiao et al. 2016). For PB1, the I368V mutation detected in a ferret adapted H5N1 strain has shown increased frequency among recent H9N2 isolates, from $2.8 \%$ to $67 \%$ (Herfst et al. 2012). In PA, the K356R mutation increased viral replication in mice even without PB2 K627. More than $80 \%$ of avian H9N2 isolates collected after 2013 and half of human H9N2 isolates contain the PA R356 marker ( $\mathrm{Xu}$ et al. 2016). A summary of molecular markers associated with transmission and adaptation of H9N2 IAV viruses is presented in Table 1.

Table 1. Molecular markers associated with adaptation and transmission of H9N2 IAV in mammalian host.

\begin{tabular}{|c|c|c|c|c|}
\hline Protein. & Marker & Effect & Host evaluated & Reference \\
\hline PB2 & T58I & Observed in airborne transmission & Ferrets & $\begin{array}{l}\text { (Kimble et al. } \\
\text { 2011) }\end{array}$ \\
\hline PB2 & $D 253 N$ & $\begin{array}{c}\text { Increase pathogenesis/Observed in airborne transmis- } \\
\text { sion }\end{array}$ & Mice and ferrets & $\begin{array}{l}\text { (Kimble et al. } \\
\text { 2014, Mok et } \\
\text { al. 2011, } \\
\text { Zhang et al. } \\
\text { 2018) }\end{array}$ \\
\hline PB2 & R340K & Increase transmission & Guinea pigs & $\begin{array}{l}\text { (Lina et al. } \\
\text { 2019) }\end{array}$ \\
\hline PB2 & Q591K & Increase polymerase complex activity and replication & Mice & $\begin{array}{c}\text { (Mok et al. } \\
\text { 2011) }\end{array}$ \\
\hline PB2 & E627K & $\begin{array}{l}\text { Increase polymerase activity and viral replication in } \\
\text { mammalian host }\end{array}$ & $\begin{array}{l}\text { Human, mice, quail, guinea pigs } \\
\text { and ferret }\end{array}$ & $\begin{array}{c}\text { (Hossain et al } \\
\text { 2008, Li et al. } \\
\text { 2004, Li et al. } \\
\text { 2014, Liu et } \\
\text { al. 2021, } \\
\text { Wang et al. } \\
\text { 2014) }\end{array}$ \\
\hline
\end{tabular}




\begin{tabular}{|c|c|c|c|c|}
\hline PB2 & $A 588 \mathrm{~V}$ & $\begin{array}{c}\text { Increase polymerase activity, transmission, and viru- } \\
\text { lence }\end{array}$ & Mice and guinea pigs & $\begin{array}{c}\text { (Lina et al. } \\
\text { 2019, Xiao et } \\
\text { al. 2016) }\end{array}$ \\
\hline PB2 & $D 701 N$ & Increase virulence and airborne transmission & Ferret & $\begin{array}{c}\text { (Li et al. } \\
\text { 2014) }\end{array}$ \\
\hline PB2 & $A 707 T$ & Observed in airborne transmission & Ferret & $\begin{array}{c}\text { (Kimble et al. } \\
\text { 2014) }\end{array}$ \\
\hline PB1 & $D 120 N$ & Observed in airborne transmission & Ferret & $\begin{array}{c}\text { (Kimble et al. } \\
\text { 2014) }\end{array}$ \\
\hline PB1 & $D 439 E$ & Observed in airborne transmission & Ferret & $\begin{array}{c}\text { (Kimble et al. } \\
\text { 2014) }\end{array}$ \\
\hline PB1 & $S 261 N$ & $\begin{array}{c}\text { Reduced polymerase complex activity/ observed in } \\
\text { airborne transmission }\end{array}$ & Ferret & $\begin{array}{l}\text { (Chin et al. } \\
\text { 2016, Kimble } \\
\text { et al. 2011) }\end{array}$ \\
\hline PB1 & $I 368 \mathrm{~V}$ & Increase airborne transmission (H5 context) & Ferret & $\begin{array}{l}\text { (Herfst et al. } \\
\text { 2012) }\end{array}$ \\
\hline$P A$ & K356R & Increase polymerase activity and replication & Mice & $\begin{array}{c}\text { (Xu et al. } \\
\text { 2016) }\end{array}$ \\
\hline$P A$ & K26E & $\begin{array}{l}\text { Increase replication/Observed in airborne transmis- } \\
\text { sion }\end{array}$ & Chickens, quail, and ferrets & $\begin{array}{c}\text { (Clements et } \\
\text { al. 2020, } \\
\text { Kimble et al. } \\
\text { 2014, Obadan } \\
\text { et al. 2019) }\end{array}$ \\
\hline HA1 & $D 225 G$ & Increase transmission and replication & Pigs & $\begin{array}{c}\text { (Mancera } \\
\text { Gracia et al. } \\
\text { 2017) }\end{array}$ \\
\hline HA1 & $Q 226 L$ & Increase $\alpha 2,6 S A$ binding & Ferrets and quails & $\begin{array}{c}\text { (Obadan et al. } \\
\text { 2019, Wan et } \\
\text { al. 2008) }\end{array}$ \\
\hline HA1 & $I 155 T$ & Increase $\alpha 2,6 S A$ binding & Ferrets & $\begin{array}{c}\text { (Li et al. } \\
\text { 2014) }\end{array}$ \\
\hline HA1 & $\begin{array}{l}\text { A190VI } \\
\text { T190V }\end{array}$ & Increase replication & Mice & $\begin{array}{l}\text { (Teng et al. } \\
\text { 2016) }\end{array}$ \\
\hline HA1 & $V 104 A$ & Observed in airborne transmission & Ferrets & $\begin{array}{c}\text { (Kimble et al. } \\
\text { 2011) }\end{array}$ \\
\hline HA1 & T189A & Increase airborne transmission & Ferrets, quails, and pigs & $\begin{array}{c}\text { (Obadan et al. } \\
\text { 2015, Sorrell } \\
\text { et al. 2009) }\end{array}$ \\
\hline HA1 & $S 263 N$ & Observed in airborne transmission & Ferrets & $\begin{array}{c}\text { (Kimble et al. } \\
\text { 2014) }\end{array}$ \\
\hline HA1 & S328C & Observed in airborne transmission & Ferrets & $\begin{array}{c}\text { (Kimble et al. } \\
\text { 2014) }\end{array}$ \\
\hline HA2 & G192R & Increase airborne transmission & Ferrets, quails, and pigs & $\begin{array}{c}\text { (Obadan et al. } \\
\text { 2015, Sorrell } \\
\text { et al. 2009) }\end{array}$ \\
\hline$N A$ & $I 28 \mathrm{~V}$ & Increase airborne transmission & Ferrets, quails, and pigs & $\begin{array}{c}\text { (Obadan et al. } \\
\text { 2015) }\end{array}$ \\
\hline$N A$ & $A 30 T$ & Observed in airborne transmission & Ferrets & $\begin{array}{c}\text { (Kimble et al. } \\
\text { 2011) }\end{array}$ \\
\hline M2 & E95K & Observed in airborne transmission & Ferrets & $\begin{array}{c}\text { (Kimble et al. } \\
\text { 2014) }\end{array}$ \\
\hline
\end{tabular}




\section{NATURAL INFECTION OF H9N2 IAV IN MAMMALS}

According to the World Health Organization (WHO), 54 human cases of H9N2 IAV infection have been reported since December 2015, with 13 cases reported during 2021 from China (as of July 222021 (WHO 2021)). Additional cases have been reported in Bangladesh, India, Egypt, Oman, and Senegal (Lin et al. 2000, Pan et al. 2018, Pawar et al. 2012, Peacock et al. 2019, Peiris et al. 1999, Potdar et al. 2019). Most human infections with H9N2 viruses had confirmed contact with poultry and evidence of human-to-human transmission has not been reported. Serological investigations have shown H9N2 IAV antibodies in humans in Vietnam, Cambodia, Iran, Thailand, Pakistan, India, Egypt, and Hong Kong (Blair et al. 2013, Chaudhry et al. 2020, Heidari et al. 2016, Hoa et al. 2017, Ma et al. 2019, Quan et al. 2019, Tahir et al. 2020). In most cases, the presence of H9N2 IAV antibodies is associated with poultry workers; however, there are seropositive cases with no history of direct poultry exposure. H9N2 IAVs have also been isolated from pigs and serological surveys have shown presence of H9N2 IAV-specific antibodies in pig herds with prevalence as high as 15\% (Cong et al. 2008, Ninomiya et al. 2002, Wang et al. 2016, Yuan et al. 2013). In addition, a serological survey showed that minks are also susceptible to infection with H9N2 IAV ( $31 \%$ of positive samples) and six different H9N2 isolates were isolated from tissues obtained from a mink farm. Similar procedures were performed in foxes and raccoon dogs (all species relevant in the fur industry), with a $59 \%$ and $41 \%$ of serologically positive samples respectively, but no virus strains were isolated (Yong-Feng et al. 2017)

\section{EXPERIMENTAL INFECTIONS/TRANSMISSION OF H9N2 IAV IN MAMMALIAN MODELS}

For an avian H9N2 virus to successfully transmit in mammals, the virus must evolve to become compatible with the new host environment, allowing effective replication and transmission(Kuiken et al. 2006). Reassortment between avian and mammalian influenza viruses has led to the emergence of pandemic viruses in the past. Transmission studies designed to evaluate the potential of IAV transmission in mammals is commonly performed in ferrets, which present similar characteristics for IAV infection as humans in terms of lung pathology, clinical signs, pathogenesis, and immunity (Maher and DeStefano 2004, Nguyen et al. 2021). Wan and collaborators evaluated replication and transmission capabilities of different H9N2 IAV isolated from avian species between 19882003, using the ferret model, showing that all the isolates replicated in ferrets. However, just 2 of those isolates transmitted through direct contact (Fig 1C). The 2 isolates that transmitted in ferrets contained the L226 HA marker, supporting the advantage of L226 over Q226 for replication in mammals. Regarding the isolates that did not transmit, two had Q226 and one L226. The role of the L226 mutation on mammalian replication and contact transmission was confirmed when it was replaced by Q226 in a H9N2 IAV isolate (L226Q), resulting in complete loss in replication capability, even in the direct inoculated group (Fig 1C). The inverse experiment, Q226L mutation introduced in a virus naturally carrying $\mathrm{Q}$ that replicated poorly in ferret without transmission, resulted in enhanced replication and transmission through direct contact (Fig 1C) (Wan et al. 2008). To further understand the relevance of amino acid 226 on HA, the replication of H9N2 viruses containing either L226 or Q226 was tested in human airway epithelial cells grown in air-liquid interface (Wan and Perez 2007). Viruses with L226 grew with higher efficiency in comparison with viruses carrying Q226, and showed a different tropism by infecting non-ciliated cells similar to seasonal human H3N2 IAV (Wan and Perez 2007). In a separated study using ex 
vivo human respiratory organ culture, H9N2 IAVs were shown to infect both the upper and lower human respiratory tract, with differences observed depending on strain (Chan et al. 2017).

More recent work demonstrated that although most H9N2 IAV isolates possess either Q226 or L226, this position is highly flexible and able to tolerate multiple amino acids (at least 10), some not previously detected in natural H9N2 isolates (Obadan et al. 2019). In vitro, most of these variants replicate to similar titers in comparison to viruses carrying either the Q226 or L226, despite their relative lower receptor binding avidity. Additionally, no impact on antigenicity or hemagglutination activity was observed, independent of the amino acid at position 226. Interestingly, viruses containing N226, M226, or I226 show increased breadth of receptor recognition, with dual binding to avian- and humantype receptors, a feature that might affect host range and potentially facilitate interspecies transmission. In contrast, viruses carrying Q226, C226, T226 or H226 show strict $\alpha 2,3$ binding, demonstrating a residue-dependency in position 226 for receptor recognition (Obadan et al. 2019). In vivo competition studies in quails using varying mixtures of these variants demonstrated that the L226 provides a fitness advantage in vivo. A mixture of viruses without Q226 or L226 (var $\Delta$ LQ) was still able to replicate and transmit via direct contact in quails, granted with lower efficiency at $2 \mathrm{dpc}$ in comparison with mixtures containing $\mathrm{L}(\operatorname{var}+\mathrm{L}), \mathrm{Q}(\operatorname{var}+\mathrm{Q})$ or both (var+LQ). Interestingly, sequencing analysis from tracheal swabs showed that even in the var $\triangle \mathrm{LQ}$ or var+Q groups, where viruses with $\mathrm{L} 226$ were not included in the mixture, $\mathrm{L}$ is still detected in the tracheal swabs collected at 3 dpi. Viruses carrying M226 or I226 were also readily detected, consistent with the detection of natural isolates containing such amino acid signatures. The predominant amino acid detected in contact quails was L226, even in groups in which quail were inoculated with the mixtures lacking L226 (var $\triangle \mathrm{LQ}$ and var+Q), suggesting a strong advantage in transmission when L226 is present. These findings confirm that L226, Q226, and M226 confer fitness advantage to H9N2 viruses in poultry, explaining their predominance in natural isolates. Although the 226 position has great plasticity, most amino acids result in strains with preference for $\alpha 2,3$-linked sialic acid and therefore, they are less likely to infect humans. This finding facilitates risk assessment for the zoonotic potential of H9N2 viruses (Obadan et al. 2019).

Despite direct-contact transmission in ferrets of the H9N2 IAV field isolates in the study described above, no airborne transmission was observed (in contrast to control ferret studies using human origin H1N1 or H3N2 IAVs) (Munster et al. 2009, Perez et al. 2009). Further, ferrets infected with a reassortant virus of the H9N2 subtype with the internal genes of a seasonal human H3N2 strain (2WF10:6M98; Fig 2A) showed clinical signs like those observed with the wild type seasonal H3N2 strain. However, direct contact (but not airborne) transmission of the 2WF10:6M98 was observed in ferrets (Fig 2B) (Wan et al. 2008). Interestingly, 10 serial passages of the 2 WF10:6M98 in ferrets resulted in a virus (P10; Fig2A) that transmitted efficiently through direct contact and by respiratory droplets (Fig 2C). The P10 virus also showed an intermediate plaque size between the seasonal H3N2 and the H9N2 viruses, suggesting an intermediary replication fitness phenotype (Sorrell et al. 2009). Sequencing of the P10 virus revealed a T189A mutation in the HA1 portion, a G192R mutation in HA2 and a I28V mutation in NA (Table 1). These mutations were crucial for the respiratory transmission phenotype observed. A L374I mutation in PB2 was also detected; however, its contribution seems to be marginal for transmission (Sorrell et al. 2009). After the emergence of the pH1N1 virus in 2009, similar experiments were performed with a reassortant $\mathrm{H} 9 \mathrm{~N} 2$ virus with $\mathrm{pH} 1 \mathrm{~N} 1$ internal genes showing that the H9N2-pH1N1 (2WF10:pH1N1) or a H9N1-pH1N1 (1WF10:pH1N1; N1 and internal genes derived from $\mathrm{pH} 1 \mathrm{N1}$; Fig 2A) are able to transmit via direct contact without prior adaptation (Kimble et al. 2011). These results suggest that in the case of H9N2 IAV, just the introduction of internal genes from human-origin IAV H1N1 or H3N2 is enough to allow an efficient direct-contact transmission in mammals (Kimble et al. 2011, Wan et al. 2008). In addition, the 2WF10:6pH1N1 virus was also able to transmit by airborne route, although with delayed replication kinetics, whereas no evidence of airborne transmission 
with 1WF10:7pH1N1 was observed, suggesting that compatibility and balance between the HA and NA is also important (Fig 2B). It is tempting to speculate that the pH1N1 backbone is more flexible to accept reassortment with diverse surface genes and does provide a replicative advantage in mammals, as has been observed in multiple examples of reassortant H1N1 and H3N2 viruses in swine (Everett et al. 2020, Powell et al. 2021, RytHansen et al. 2020, Zell et al. 2020). Sequencing information showed a S261N mutation in PB1 and V104A in HA in the viruses isolated from respiratory contact animals (Table 1); however, the role of those positions in airborne transmission remains unknown (Kimble et al. 2011). When pH1N1 internal genes are combined with the H9 HA (1P10:7pH1N1) or H9N2 HA/NA (2P10:6pH1N1) of the P10 ferret-adapted virus (Fig 2A), both viruses show efficient replication in vitro, generate moderate to severe lesions in the respiratory tract of ferrets and both are able to efficiently transmit via direct contact and respiratory droplets in the ferret system, (Kimble et al. 2011) (Fig 2C). Furthermore, these viruses efficiently transmitted between pigs by direct contact while only the 2P10:6pH1N1 transmitted in quails (Obadan et al. 2015). 


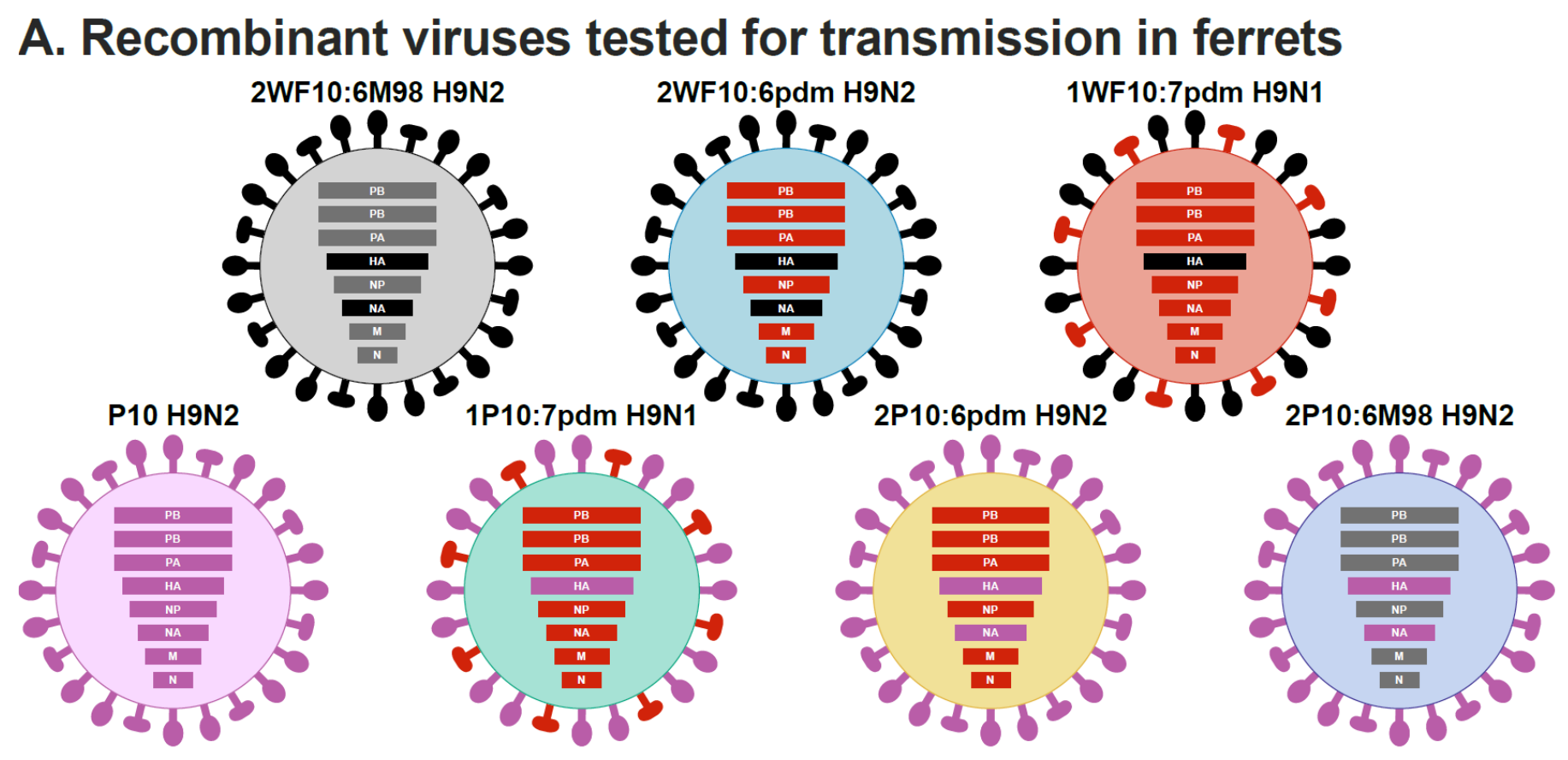

\section{B. Transmission of reassortant H9N2 viruses in ferrets}

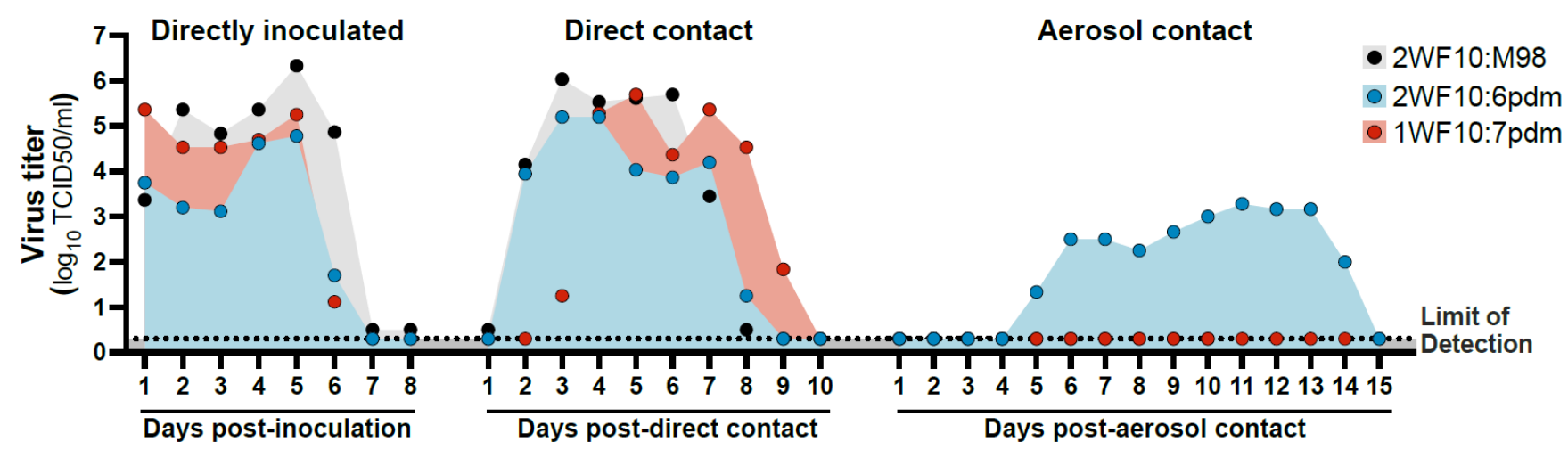

\section{Transmission of ferret-adapted H9N2 viruses in ferrets}

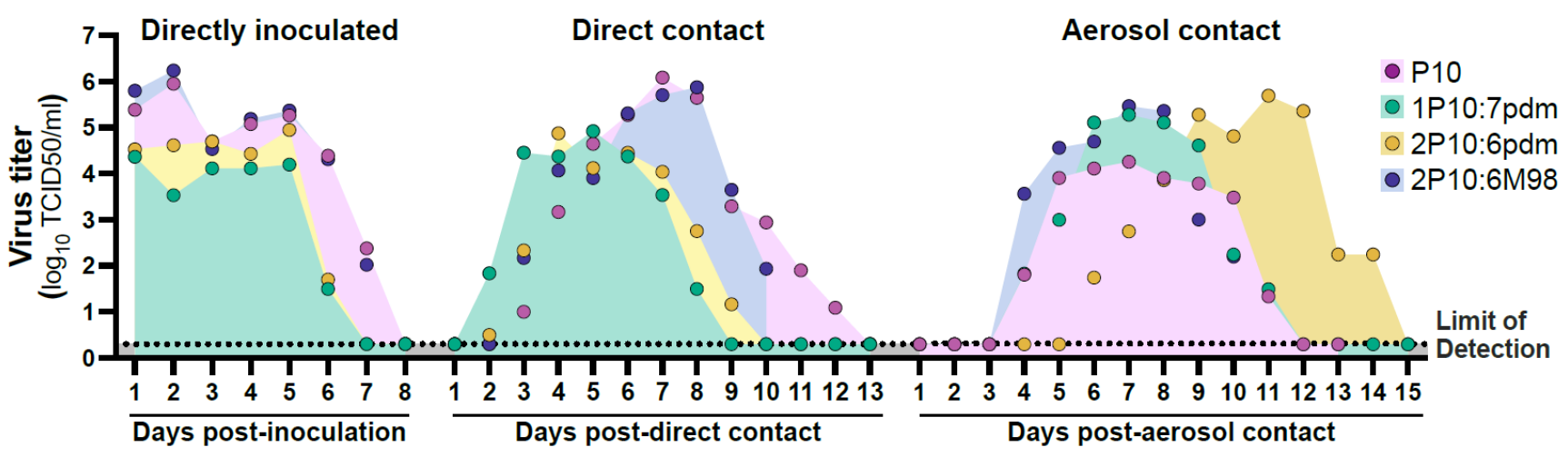

Figure 2. Transmission of reassortant and adapted $\mathrm{H9}$ viruses in ferrets. (A) Schematic representation of the different reassortant viruses evaluated in ferrets. (B) Replication and transmission by direct contact or airborne in ferrets of viruses carrying the H9N2 subtype with internal genes of a seasonal H3N2 virus (2WF10:M98 H9N2) or pandemic H1N1 virus (2WF10:6pdm H9N2 or 1WF10:7pdm H9N1). (C) Replication and transmission by direct contact or airborne in ferrets of a virus carrying the H9N2 subtype with internal genes of a seasonal H3N2 virus adapted by serial passages in ferrets (P10). Viruses containing the HA (1P10:7pdm) or the HA/NA (2P10:6pdm) of the P10 virus and internal genes of a pandemic 
H1N1 virus, or HA/NA of the P10 virus and internal genes of a seasonal H3N2 (2P10:6M98) were also evaluated. Results compiled from (Kimble et al. 2011, Sorrell et al. 2009, Wan et al. 2008).

To confirm the role of reassortment (and presence of mammalian-adapted gene segments) on the ability of $\mathrm{H} 9$ viruses to transmit in mammals, a transfection-based inoculation (TBI) study was performed in ferrets to select airborne transmissible H9 reassortant viruses under host selection pressure. In brief, ferrets were inoculated with cells previously transfected with 15 plasmids: 6 encoding the internal gene segments of the WF10 H9N2 virus, 7 gene segments (excluding the HA) of a prototypic pH1N1 virus and the surface gene segments of the P10 ferret-adapted virus. The resulting virus mixture was then serially passaged in ferrets, allowing for the selection of any possible $\mathrm{H} 9$ reassortant that was compatible/fit with respiratory droplet transmission in ferrets. The results show two different H9N1 viruses that were selected and able to transmit by the respiratory route in ferrets (Kimble et al. 2014). Both H9N1 viruses identified had a mixed population of internal genes from pH1N1 or H9N2, both containing PB2, NP and NA of from the pH1N1 strain and PA, HA and NS from the H9N2 strain. Both viruses differed in the PB1 and $\mathrm{M}$ gene segments where in one virus both were from $\mathrm{pH} 1 \mathrm{~N} 1 \mathrm{strain}$, and the opposite was observed in the second virus. Sequencing analysis revealed mutations in PB2 (D253N), PA (K26E), HA1 (S263N) and NS (D2N) in one of the viruses (Table 1), some of which have been previously reported to have an impact replication and pathogenicity (Clements et al. 2020, Forbes et al. 2012, Mok et al. 2011, Ping et al. 2011, Zhang et al. 2018). The second virus showed mutations in PB2 (A707T), HA1 (S328C), M2 (E95K), and two mutations in PB1 (D120N and D439E) (Table 1) (Kimble et al. 2014). However, the mutations detected in the second virus have not been associated with any advantage in terms of replication or pathogenicity previously, highlighting that the molecular requirements for efficient transmission of H9N2 IAV viruses in mammalian species are far from understood and deserves further scrutiny. A summary of the different viruses discussed above, and the transmission phenotype is shown in Figure 3. 


\begin{tabular}{|c|c|c|c|c|c|}
\hline VIRUS & DESCRIPTION & TRANSMISSIOI & DIRECT CONTA & AEROSOL & REFERENCE \\
\hline 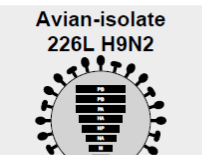 & $\begin{array}{l}\text { IAV H9N2 viruses isolated from } \\
\text { avian species carrying } 226 \mathrm{~L} \text { in } \\
\text { the HA }\end{array}$ & $\begin{array}{l}\text { Direct contact }(66 \%) \\
\text { No Aerosol transmission }\end{array}$ & $\mathrm{N} / \mathrm{D}$ & $\begin{array}{c}\text { Direct contact } \\
\text { depending on strain }\end{array}$ & 59 \\
\hline 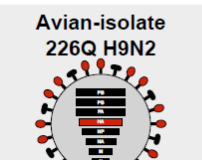 & $\begin{array}{l}\text { IAV H9N2 viruses isolated from } \\
\text { avian species carrying } 226 Q \text { in } \\
\text { the HA }\end{array}$ & No transmission & N/D & $\begin{array}{c}\text { Direct contact } \\
\text { depending on strain }\end{array}$ & 59 \\
\hline 2WF10:6M98 H9N2 & $\begin{array}{l}\text { Recombinant H9N2 virus with } \\
\text { internal genes from a seasonal } \\
\text { IAV H3N2 }\end{array}$ & $\begin{array}{l}\text { Direct contact } \\
\text { No Aerosol transmission }\end{array}$ & N/D & N/D & 59,94 \\
\hline 2WF10:6pdm H9N2 & $\begin{array}{l}\text { Recombinant H9N2 virus with } \\
\text { internal genes from a pandemic } \\
\text { IAV H1N1 }\end{array}$ & $\begin{array}{l}\text { Direct contact } \\
\text { Aerosol transmission }\end{array}$ & N/D & N/D & 95 \\
\hline 1WF10:7pdm H9N1 & $\begin{array}{l}\text { Recombinant H9N1 virus with } \\
\text { internal genes and NA from a } \\
\text { pandemic IAV H1N1 }\end{array}$ & $\begin{array}{l}\text { Direct contact } \\
\text { No Aerosol transmission }\end{array}$ & N/D & N/D & 95 \\
\hline 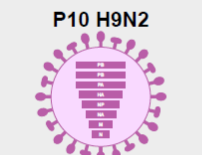 & $\begin{array}{l}\text { Recombinant H9N2 virus with } \\
\text { internal genes from a seasonal } \\
\text { IAV H3N2 adapted by } 10 \text { serial } \\
\text { passages in ferrets }\end{array}$ & $\begin{array}{l}\text { Direct contact } \\
\text { Aerosol transmission }\end{array}$ & N/D & N/D & 94 \\
\hline 1P10:7pdm H9N1 & $\begin{array}{l}\text { Recombinant H9N1 virus (HA } \\
\text { from P10 virus) with internal } \\
\text { genes and NA from a pandemic } \\
\text { IAV H1N1 }\end{array}$ & $\begin{array}{l}\text { Direct contact } \\
\text { Aerosol transmission }\end{array}$ & Direct contact & No Direct contact & 95,100 \\
\hline 2P10:6pdm H9N2 & $\begin{array}{l}\text { Recombinant H9N2 virus (HA } \\
\text { and NA from P10 virus) with in- } \\
\text { ternal genes from a pandemic } \\
\text { IAV H1N1 }\end{array}$ & $\begin{array}{l}\text { Direct contact } \\
\text { Aerosol transmission }\end{array}$ & Direct contact & Direct contact & 95,100 \\
\hline 2P10:6M98 H9N2 & $\begin{array}{l}\text { Recombinant H9N2 virus (HA } \\
\text { and NA from P10 virus) with in- } \\
\text { ternal genes from a seasonal } \\
\text { IAV H3N2 }\end{array}$ & $\begin{array}{l}\text { Direct contact } \\
\text { Aerosol transmission }\end{array}$ & N/D & N/D & 94 \\
\hline
\end{tabular}

Figure 3. Summary of H9 IAV reassortant viruses and their transmission ability in ferrets. Schematic representation of the different $\mathrm{H} 9$ viruses tested for transmission in ferrets by our group and described in this review, description of each virus, and type of transmission observed. Results compiled from (Kimble et al. 2011, Obadan et al. 2015, Sorrell et al. 2009, Wan et al. 2008).

Experimental infection/transmission with poultry adapted H9N2 viruses have been evaluated also in multiple alternative animal models such as guinea pigs, mice, and pigs, among others (Table 2) (Kimble et al. 2011, Lina et al. 2019, Sorrell et al. 2009, Wan et al. 2008, Wang et al. 2016, Yong-Feng et al. 2017). In one study, experimental infection of 
pigs with H9N2 resulted in nasal shedding and seroconversion with 4 out of 6 H9N2 IAV isolates (Wang et al. 2016); however, transmission between pigs did not occur. When the internal gene segments were replaced with those from a pandemic H1N1 strain, increased virus replication and transmission between pigs was observed (Obadan et al. 2015, Qiao et al. 2012). Furthermore, when an H9N2 virus with the pH1N1 internal gene segments was serially passaged in pigs, the virus showed increased tropism capable of replicating in the entire respiratory tract as well as efficient pig-to-pig transmission (Mancera Gracia et al. 2017).

Some H9N2 IAV strains isolated from chicken houses were able to transmit experimentally between guinea pigs by direct contact but respiratory droplets transmission was not observed (Lv et al. 2012). Interestingly, direct contact transmission efficacy increased after nine serial passages of H9N2 IAV in guinea pigs, reaching 100\% transmission after fifteen serial passages, consistent with the idea that molecular adaptative changes are required to result in a mammalian transmissible H9N2 virus. However, despite the improvement of direct contact transmission after fifteen passages, airborne transmission had only $16 \%$ efficacy in guinea pigs and no airborne transmission was observed in ferrets (Sang et al. 2015). Similarly, improvement in transmissibility is also achieved in guinea pigs when H9N2 IAV are serially passaged in mice prior to guinea pig infection. The mouse adapted H9N2 IAV has enhanced pathogenicity and is able to transmit through direct contact and respiratory droplets whereas the non-mouse adapted version does not transmit in guinea pigs (Lina et al. 2019). Reassortant viruses carrying unmodified H9N2 glycoproteins and internal genes derived from $\mathrm{pH} 1 \mathrm{~N} 1$ were also able to transmit by either direct contact or airborne in guinea pigs whereas a whole avian H9N2 virus did not (He et al. 2014), similarly to what was observed in pigs. The presence of pH1N1 PA gene alone seems to be sufficient to allow transmission between guinea pigs by direct contact but not respiratory droplets (Hao et al. 2019).

Further, H9N2 IAV isolated from live bird markets possessing L226/S228 in the HA plus K627 in the PB2 (all molecular markers of mammalian adaptation and/or respiratory tissue adaptation) can transmit via airborne between chickens and guinea pigs (Liu et al. 2021). Further, transmission studies in ferrets using H9N2 viruses have shown some natural avian-origin H9N2 IAV isolates are able to transmit via respiratory droplets in ferrets without further adaptation (Li et al. 2014, Wan et al. 2008, Zhang et al. 2021), highlighting the inherent risk for H9N2 IAV transmission in mammalian species and suggesting a strain-specific effect. Similarly, H9N2 viruses isolated from humans were able to transmit via direct contact and respiratory droplets in 1 out of 3 isolates evaluated. However, in that study, swine- and avian-origin H9N2 isolates were only able to transmit via direct contact (Group 2013). Direct-contact transmission of H9N2 IAV can also occur between minks, foxes, or raccoon dogs (Yong-Feng et al. 2017). Contact minks developed clinical signs consistent with H9N2 IAV infection whereas seroconversion, but no clinical signs, was observed in foxes and raccoon dogs (Yong-Feng et al. 2017). In another study, the airborne transmission of H9N2 IAV was evaluated in minks, but no positive results were obtained (Sun et al. 2021). H9N2 IAV infection was also reported in experimentally infected cats and dogs but transmission through direct contact was only observed among cats but not dogs (Zhang et al. 2013).

\section{CONCLUSIONS}

Although H9N2 IAV are LPAIV and cause mostly mild infections, these viruses still result in significant economic losses to the poultry industry. Furthermore, H9N2 IAV have been implicated as the donors of internal genes for prevalent HPAIV outbreaks that have resulted in human infections in some cases. Additionally, cases of H9N2 IAV have been reported in different mammalian species including humans, demonstrating their risk to public health and pandemic potential. Though most infections do not result in mammalian-to-mammalian transmission, different experiments have demonstrated that 
transmission of H9N2 IAV in mammals is possible. Nevertheless, adaptation or reassortment with mammalian-adapted internal genes is required for an efficient transmission between mammals, particularly by the respiratory route, although airborne transmission of natural isolates has been observed. Therefore, continued surveillance and research to understand the evolution, pathogenicity, transmission, and antigenicity of H9N2 IAV is needed. Furthermore, understanding the molecular traits that facilitate transmission of H9N2 to and between mammals is crucial to evaluate their pandemic potential and to allow timely identification of viruses with increased potential for interspecies transmission.

\section{FUNDING}

This work was supported in part by a subcontract from the Center for Research on Influenza Pathogenesis (CRIP) to D.R.P. under contract HHSN272201400008C from the National Institute of Allergy and Infectious Diseases (NIAID) Centers for Influenza Research and Surveillance (CEIRS).

\section{ACKNOWLEDGMENTS}

We would like to acknowledge former and current member of the Rajao/Perez Lab for their contribution to the different studies summarized in this review. We would like to also thank all the investigators that have contributed to the different articles cited in this review. Special thanks to the Georgia Research Alliance and the Georgia Poultry Federation through the Caswell S. Eidson in Poultry Medicine endowment chair.

\section{ORCID}

C. Joaquin Caceres: https://orcid.org/0000-0001-8508-6592

Daniel R. Perez: https://orcid.org/0000-0002-6569-5689

Daniela S. Rajao: https://orcid.org/0000-0002-0772-0065

\section{REFERENCES}

1. Krammer, F.; Smith, G.J.D.; Fouchier, R.A.M.; Peiris, M.; Kedzierska, K.; Doherty, P.C.; Palese, P.; Shaw, M.L.; Treanor, J.; Webster, R.G.; et al. Influenza. Nat Rev Dis Primers 2018, 4, 3, doi:10.1038/s41572-018-0002-y.

2. Peacock, T.H.P.; James, J.; Sealy, J.E.; Iqbal, M. A Global Perspective on H9N2 Avian Influenza Virus. Viruses 2019, 11, doi:10.3390/v11070620.

3. Carnaccini, S.; Perez, D.R. H9 Influenza Viruses: An Emerging Challenge. Cold Spring Harb Perspect Med 2020, 10, doi:10.1101/cshperspect.a038588.

4. Berhane, Y.; Hisanaga, T.; Kehler, H.; Neufeld, J.; Manning, L.; Argue, C.; Handel, K.; HooperMcGrevy, K.; Jonas, M.; Robinson, J.; et al. Highly pathogenic avian influenza virus A (H7N3) in domestic poultry, Saskatchewan, Canada, 2007. Emerg Infect Dis 2009, 15, 1492-1495, doi:10.3201/eid1509.080231.

5. Choi, Y.K.; Ozaki, H.; Webby, R.J.; Webster, R.G.; Peiris, J.S.; Poon, L.; Butt, C.; Leung, Y.H.; Guan, Y. Continuing evolution of H9N2 influenza viruses in Southeastern China. J Virol 2004, 78, 8609-8614, doi:10.1128/JVI.78.16.8609-8614.2004. 
6. Morales, A.C., Jr.; Hilt, D.A.; Williams, S.M.; Pantin-Jackwood, M.J.; Suarez, D.L.; Spackman, E.; Stallknecht, D.E.; Jackwood, M.W. Biologic characterization of H4, H6, and H9 type low pathogenicity avian influenza viruses from wild birds in chickens and turkeys. Avian Dis 2009, 53, 552-562, doi:10.1637/8877-041509-Reg.1.

7. Banet-Noach, C.; Perk, S.; Simanov, L.; Grebenyuk, N.; Rozenblut, E.; Pokamunski, S.; Pirak, M.; Tendler, Y.; Panshin, A. H9N2 influenza viruses from Israeli poultry: a five-year outbreak. Avian Dis 2007, 51, 290-296.

8. Monne, I.; Hussein, H.A.; Fusaro, A.; Valastro, V.; Hamoud, M.M.; Khalefa, R.A.; Dardir, S.N.; Radwan, M.I.; Capua, I.; Cattoli, G. H9N2 influenza A virus circulates in H5N1 endemically infected poultry population in Egypt. Influenza Other Respir Viruses 2013, 7, 240-243, doi:10.1111/j.17502659.2012.00399.x.

9. Sonnberg, S.; Phommachanh, P.; Naipospos, T.S.; McKenzie, J.; Chanthavisouk, C.; Pathammavong, S.; Darnell, D.; Meeduangchanh, P.; Rubrum, A.M.; Souriya, M.; et al. Multiple introductions of avian influenza viruses (H5N1), Laos, 2009-2010. Emerg Infect Dis 2012, 18, 1139-1143, doi:10.3201/eid1807.111642.

10. Alexander, D.J. Should we change the definition of avian influenza for eradication purposes? Avian Dis 2003, 47, 976-981, doi:10.1637/0005-2086-47.s3.976.

11. Organization, W.H. Avian influenza: assessing the pandemic threat. 2005.

12. Service, U.A.a.P.H.I. Avian Influenza (Al). Available online: https://www.aphis.usda.gov/aphis/ourfocus/animalhealth/nvap/NVAP-ReferenceGuide/Poultry/Avian-Influenza (accessed on

13. Swieton, E.; Tarasiuk, K.; Olszewska-Tomczyk, M.; Iwan, E.; Smietanka, K. A Turkey-origin H9N2 Avian Influenza Virus Shows Low Pathogenicity but Different Within-Host Diversity in Experimentally Infected Turkeys, Quail and Ducks. Viruses 2020, 12, doi:10.3390/v12030319.

14. Xu, K.M.; Li, K.S.; Smith, G.J.; Li, J.W.; Tai, H.; Zhang, J.X.; Webster, R.G.; Peiris, J.S.; Chen, H.; Guan, $\mathrm{Y}$. Evolution and molecular epidemiology of H9N2 influenza A viruses from quail in southern China, 2000 to 2005. J Virol 2007, 81, 2635-2645, doi:10.1128/JVI.02316-06.

15. Hassan, M.M.; El Zowalaty, M.E.; Islam, A.; Khan, S.A.; Rahman, M.K.; Jarhult, J.D.; Hoque, M.A. Prevalence and Diversity of Avian Influenza Virus Hemagglutinin Sero-Subtypes in Poultry and Wild Birds in Bangladesh. Vet Sci 2020, 7, doi:10.3390/vetsci7020073.

16. Jackwood, M.W.; Stallknecht, D.E. Molecular epidemiologic studies on North American H9 avian influenza virus isolates from waterfowl and shorebirds. Avian Dis 2007, 51, 448-450, doi:10.1637/7536-032706R.1.

17. Swieton, E.; Jozwiak, M.; Minta, Z.; Smietanka, K. Genetic characterization of H9N2 avian influenza viruses isolated from poultry in Poland during 2013/2014. Virus Genes 2018, 54, 67-76, doi:10.1007/s11262-017-1513-4.

18. Reid, S.M.; Banks, J.; Ceeraz, V.; Seekings, A.; Howard, W.A.; Puranik, A.; Collins, S.; Manvell, R.; Irvine, R.M.; Brown, I.H. The Detection of a Low Pathogenicity Avian Influenza Virus Subtype H9 Infection in a Turkey Breeder Flock in the United Kingdom. Avian Dis 2016, 60, 126-131, doi:10.1637/11356-122315-Case.1.

19. Homme, P.J.; Easterday, B.C. Avian influenza virus infections. IV. Response of pheasants, ducks, and geese to influenza A-turkey-Wisconsin-1966 virus. Avian Dis 1970, 14, 285-290. 
20. Markwell, D.D.; Shortridge, K.F. Possible waterborne transmission and maintenance of influenza viruses in domestic ducks. Appl Environ Microbiol 1982, 43, 110-115, doi:10.1128/AEM.43.1.110115.1982.

21. Shortridge, K.F. Pandemic influenza: a zoonosis? Semin Respir Infect 1992, 7, 11-25.

22. Perez, D.R.; Lim, W.; Seiler, J.P.; Yi, G.; Peiris, M.; Shortridge, K.F.; Webster, R.G. Role of quail in the interspecies transmission of $\mathrm{H} 9$ influenza $A$ viruses: molecular changes on $\mathrm{HA}$ that correspond to adaptation from ducks to chickens. J Virol 2003, 77, 3148-3156, doi:10.1128/jvi.77.5.31483156.2003.

23. Guan, Y.; Shortridge, K.F.; Krauss, S.; Chin, P.S.; Dyrting, K.C.; Ellis, T.M.; Webster, R.G.; Peiris, M. H9N2 influenza viruses possessing H5N1-like internal genomes continue to circulate in poultry in southeastern China. J Virol 2000, 74, 9372-9380, doi:10.1128/jvi.74.20.9372-9380.2000.

24. Cameron, K.R.; Gregory, V.; Banks, J.; Brown, I.H.; Alexander, D.J.; Hay, A.J.; Lin, Y.P. H9N2 subtype influenza $A$ viruses in poultry in pakistan are closely related to the H9N2 viruses responsible for human infection in Hong Kong. Virology 2000, 278, 36-41, doi:10.1006/viro.2000.0585.

25. Bonfante, F.; Mazzetto, E.; Zanardello, C.; Fortin, A.; Gobbo, F.; Maniero, S.; Bigolaro, M.; Davidson, I.; Haddas, R.; Cattoli, G.; et al. A G1-lineage H9N2 virus with oviduct tropism causes chronic pathological changes in the infundibulum and a long-lasting drop in egg production. Vet Res 2018, 49, 83, doi:10.1186/s13567-018-0575-1.

26. Sid, H.; Hartmann, S.; Winter, C.; Rautenschlein, S. Interaction of Influenza A Viruses with Oviduct Explants of Different Avian Species. Front Microbiol 2017, 8, 1338, doi:10.3389/fmicb.2017.01338.

27. Qi, X.; Tan, D.; Wu, C.; Tang, C.; Li, T.; Han, X.; Wang, J.; Liu, C.; Li, R.; Wang, J. Deterioration of eggshell quality in laying hens experimentally infected with H9N2 avian influenza virus. Vet Res 2016, 47, 35, doi:10.1186/s13567-016-0322-4.

28. Nili, H.; Asasi, K. Natural cases and an experimental study of H9N2 avian influenza in commercial broiler chickens of Iran. Avian Pathol 2002, 31, 247-252, doi:10.1080/03079450220136567.

29. Jakhesara, S.J.; Bhatt, V.D.; Patel, N.V.; Prajapati, K.S.; Joshi, C.G. Isolation and characterization of H9N2 influenza virus isolates from poultry respiratory disease outbreak. Springerplus 2014, 3, 196, doi:10.1186/2193-1801-3-196.

30. Smietanka, K.; Minta, Z.; Swieton, E.; Olszewska, M.; Jozwiak, M.; Domanska-Blicharz, K.; Wyrostek, K.; Tomczyk, G.; Pikula, A. Avian influenza H9N2 subtype in Poland--characterization of the isolates and evidence of concomitant infections. Avian Pathol 2014, 43, 427-436, doi:10.1080/03079457.2014.952221.

31. Wang, J.; Tang, C.; Wang, Q.; Li, R.; Chen, Z.; Han, X.; Wang, J.; Xu, X. Apoptosis induction and release of inflammatory cytokines in the oviduct of egg-laying hens experimentally infected with H9N2 avian influenza virus. Vet Microbiol 2015, 177, 302-314, doi:10.1016/j.vetmic.2015.04.005.

32. Awuni, J.A.; Bianco, A.; Dogbey, O.J.; Fusaro, A.; Yingar, D.T.; Salviato, A.; Ababio, P.T.; Milani, A.; Bonfante, F.; Monne, I. Avian influenza H9N2 subtype in Ghana: virus characterization and evidence of co-infection. Avian Pathol 2019, 48, 470-476, doi:10.1080/03079457.2019.1624687.

33. Arafat, N.; Abd El Rahman, S.; Naguib, D.; El-Shafei, R.A.; Abdo, W.; Eladl, A.H. Co-infection of Salmonella enteritidis with H9N2 avian influenza virus in chickens. Avian Pathol 2020, 49, 496-506, doi:10.1080/03079457.2020.1778162. 
34. Chu, J.; Zhang, Q.; Zuo, Z.; El-Ashram, S.; Guo, Y.; Zhao, P.; Huang, S.; He, C.; Khan, A. Co-infection of Chlamydia psittaci with H9N2, ORT and Aspergillus fumigatus contributes to severe pneumonia and high mortality in SPF chickens. Sci Rep 2017, 7, 13997, doi:10.1038/s41598-017-14519-1.

35. Wiley, D.C.; Wilson, I.A.; Skehel, J.J. Structural identification of the antibody-binding sites of Hong Kong influenza haemagglutinin and their involvement in antigenic variation. Nature 1981, 289, 373378.

36. Li, J.; Gu, M.; Liu, K.; Gao, R.; Sun, W.; Liu, D.; Jiang, K.; Zhong, L.; Wang, X.; Hu, J.; et al. Amino acid substitutions in antigenic region $B$ of hemagglutinin play a critical role in the antigenic drift of subclade 2.3.4.4 highly pathogenic H5NX influenza viruses. Transbound Emerg Dis 2020, 67, 263275, doi:10.1111/tbed.13347.

37. Kaverin, N.V.; Rudneva, I.A.; Ilyushina, N.A.; Lipatov, A.S.; Krauss, S.; Webster, R.G. Structural differences among hemagglutinins of influenza $A$ virus subtypes are reflected in their antigenic architecture: analysis of H9 escape mutants. J Virol 2004, 78, 240-249, doi:10.1128/jvi.78.1.240249.2004.

38. Peacock, T.; Reddy, K.; James, J.; Adamiak, B.; Barclay, W.; Shelton, H.; Iqbal, M. Antigenic mapping of an H9N2 avian influenza virus reveals two discrete antigenic sites and a novel mechanism of immune escape. Sci. Rep. 2016, 6, 18745, doi:10.1038/srep18745.

39. Wei, Y.; Xu, G.; Zhang, G.; Wen, C.; Anwar, F.; Wang, S.; Lemmon, G.; Wang, J.; Carter, R.; Wang, M.; et al. Antigenic evolution of H9N2 chicken influenza viruses isolated in China during 2009-2013 and selection of a candidate vaccine strain with broad cross-reactivity. Vet Microbiol 2016, 182, 1-7, doi:10.1016/j.vetmic.2015.10.031.

40. Adel, A.; Arafa, A.; Hussein, H.A.; El-Sanousi, A.A. Molecular and antigenic traits on hemagglutinin gene of avian influenza H9N2 viruses: Evidence of a new escape mutant in Egypt adapted in quails. Res Vet Sci 2017, 112, 132-140, doi:10.1016/j.rvsc.2017.02.003.

41. Lam, T.T.; Wang, J.; Shen, Y.; Zhou, B.; Duan, L.; Cheung, C.L.; Ma, C.; Lycett, S.J.; Leung, C.Y.; Chen, $X . ;$ et al. The genesis and source of the H7N9 influenza viruses causing human infections in China. Nature 2013, 502, 241-244, doi:10.1038/nature12515.

42. Guan, Y.; Shortridge, K.F.; Krauss, S.; Webster, R.G. Molecular characterization of H9N2 influenza viruses: were they the donors of the "internal" genes of H5N1 viruses in Hong Kong? Proc. Natl. Acad. Sci. U. S. A. 1999, 96, 9363-9367.

43. Pu, J.; Yin, Y.; Liu, J.; Wang, X.; Zhou, Y.; Wang, Z.; Sun, Y.; Sun, H.; Li, F.; Song, J.; et al. Reassortment with dominant chicken H9N2 influenza virus contributed to the fifth H7N9 virus human epidemic. $J$ Virol 2021, doi:10.1128/JVI.01578-20.

44. Wang, Y.; Niu, S.; Zhang, B.; Yang, C.; Zhou, Z. The whole genome analysis for the first human infection with H10N3 influenza virus in China. J Infect 2021, doi:10.1016/j.jinf.2021.06.021.

45. Peiris, M.; Yuen, K.Y.; Leung, C.W.; Chan, K.H.; Ip, P.L.; Lai, R.W.; Orr, W.K.; Shortridge, K.F. Human infection with influenza H9N2. Lancet 1999, 354, 916-917, doi:10.1016/s0140-6736(99)03311-5.

46. Butt, K.M.; Smith, G.J.; Chen, H.; Zhang, L.J.; Leung, Y.H.; Xu, K.M.; Lim, W.; Webster, R.G.; Yuen, K.Y.; Peiris, J.S.; et al. Human infection with an avian H9N2 influenza A virus in Hong Kong in 2003. J Clin Microbiol 2005, 43, 5760-5767, doi:10.1128/JCM.43.11.5760-5767.2005.

47. Jallow, M.M.; Fall, A.; Barry, M.A.; Diop, B.; Sy, S.; Goudiaby, D.; Fall, M.; Enouf, V.; Niang, M.N.; Dia, N. Genetic characterization of the first detected human case of low pathogenic avian influenza 
A/H9N2 in sub-Saharan Africa, Senegal. Emerg Microbes Infect 2020, 9, 1092-1095, doi:10.1080/22221751.2020.1763858.

48. Sun, H.; Li, F.; Liu, Q.; Du, J.; Liu, L.; Sun, H.; Li, C.; Liu, J.; Zhang, X.; Yang, J.; et al. Mink is a highly susceptible host species to circulating human and avian influenza viruses. Emerg Microbes Infect 2021, 1-34, doi:10.1080/22221751.2021.1899058.

49. Cong, Y.L.; Wang, C.F.; Yan, C.M.; Peng, J.S.; Jiang, Z.L.; Liu, J.H. Swine infection with H9N2 influenza viruses in China in 2004. Virus Genes 2008, 36, 461-469, doi:10.1007/s11262-008-0227-z.

50. Van Hoeven, N.; Pappas, C.; Belser, J.A.; Maines, T.R.; Zeng, H.; Garcia-Sastre, A.; Sasisekharan, R.; Katz, J.M.; Tumpey, T.M. Human HA and polymerase subunit PB2 proteins confer transmission of an avian influenza virus through the air. Proc Natl Acad Sci U S A 2009, 106, 3366-3371, doi:10.1073/pnas.0813172106.

51. Edinger, T.O.; Pohl, M.O.; Stertz, S. Entry of influenza A virus: host factors and antiviral targets. J Gen Virol 2014, 95, 263-277, doi:10.1099/vir.0.059477-0.

52. Das, D.K.; Govindan, R.; Nikic-Spiegel, I.; Krammer, F.; Lemke, E.A.; Munro, J.B. Direct Visualization of the Conformational Dynamics of Single Influenza Hemagglutinin Trimers. Cell 2018, 174, 926-937 e912, doi:10.1016/j.cell.2018.05.050.

53. Xiong, X.; McCauley, J.W.; Steinhauer, D.A. Receptor binding properties of the influenza virus hemagglutinin as a determinant of host range. Curr Top Microbiol Immunol 2014, 385, 63-91, doi:10.1007/82_2014_423.

54. Rogers, G.N.; Paulson, J.C.; Daniels, R.S.; Skehel, J.J.; Wilson, I.A.; Wiley, D.C. Single amino acid substitutions in influenza haemagglutinin change receptor binding specificity. Nature 1983, 304, 7678, doi:10.1038/304076a0.

55. Wan, H.; Perez, D.R. Amino acid 226 in the hemagglutinin of H9N2 influenza viruses determines cell tropism and replication in human airway epithelial cells. J Virol 2007, 81, 5181-5191, doi:10.1128/JVI.02827-06.

56. Obadan, A.O.; Santos, J.; Ferreri, L.; Thompson, A.J.; Carnaccini, S.; Geiger, G.; Gonzalez Reiche, A.S.; Rajao, D.S.; Paulson, J.C.; Perez, D.R. Flexibility In Vitro of Amino Acid 226 in the Receptor-Binding Site of an H9 Subtype Influenza A Virus and Its Effect In Vivo on Virus Replication, Tropism, and Transmission. J. Virol. 2019, 93, doi:10.1128/jvi.02011-18.

57. Sun, X.; Belser, J.A.; Maines, T.R. Adaptation of H9N2 Influenza Viruses to Mammalian Hosts: A Review of Molecular Markers. Viruses 2020, 12, doi:10.3390/v12050541.

58. Vines, A.; Wells, K.; Matrosovich, M.; Castrucci, M.R.; Ito, T.; Kawaoka, Y. The role of influenza A virus hemagglutinin residues 226 and 228 in receptor specificity and host range restriction. $J$ Virol 1998, 72, 7626-7631, doi:10.1128/JVI.72.9.7626-7631.1998.

59. Wan, H.; Sorrell, E.M.; Song, H.; Hossain, M.J.; Ramirez-Nieto, G.; Monne, I.; Stevens, J.; Cattoli, G.; Capua, I.; Chen, L.M.; et al. Replication and transmission of H9N2 influenza viruses in ferrets: evaluation of pandemic potential. PLoS One 2008, 3, e2923, doi:10.1371/journal.pone.0002923.

60. Zou, S.; Zhang, Y.; Li, X.; Bo, H.; Wei, H.; Dong, L.; Yang, L.; Dong, J.; Liu, J.; Shu, Y.; et al. Molecular characterization and receptor binding specificity of H9N2 avian influenza viruses based on poultryrelated environmental surveillance in China between 2013 and 2016. Virology 2019, 529, 135-143, doi:10.1016/j.virol.2019.01.002.

61. Matrosovich, M.N.; Krauss, S.; Webster, R.G. H9N2 influenza A viruses from poultry in Asia have human virus-like receptor specificity. Virology 2001, 281, 156-162, doi:10.1006/viro.2000.0799. 
62. Li, X.; Shi, J.; Guo, J.; Deng, G.; Zhang, Q.; Wang, J.; He, X.; Wang, K.; Chen, J.; Li, Y.; et al. Genetics, Receptor Binding Property, and Transmissibility in Mammals of Naturally Isolated H9N2 Avian Influenza Viruses. PLoS Pathog 2014, 10, e1004508, doi:10.1371/journal.ppat.1004508.

63. Teng, Q.; Xu, D.; Shen, W.; Liu, Q.; Rong, G.; Li, X.; Yan, L.; Yang, J.; Chen, H.; Yu, H.; et al. A Single Mutation at Position 190 in Hemagglutinin Enhances Binding Affinity for Human Type Sialic Acid Receptor and Replication of H9N2 Avian Influenza Virus in Mice. J Virol 2016, 90, 9806-9825, doi:10.1128/JVI.01141-16.

64. Matrosovich, M.; Tuzikov, A.; Bovin, N.; Gambaryan, A.; Klimov, A.; Castrucci, M.R.; Donatelli, I.; Kawaoka, Y. Early alterations of the receptor-binding properties of $\mathrm{H} 1, \mathrm{H} 2$, and $\mathrm{H} 3$ avian influenza virus hemagglutinins after their introduction into mammals. J. Virol. 2000, 74, 8502-8512.

65. Wang, D.; Yang, L.; Gao, R.; Zhang, X.; Tan, Y.; Wu, A.; Zhu, W.; Zhou, J.; Zou, S.; Li, X.; et al. Genetic tuning of the novel avian influenza $A(H 7 N 9)$ virus during interspecies transmission, China, 2013. Euro Surveill 2014, 19, doi:10.2807/1560-7917.es2014.19.25.20836.

66. Li, K.S.; Guan, Y.; Wang, J.; Smith, G.J.; Xu, K.M.; Duan, L.; Rahardjo, A.P.; Puthavathana, P.; Buranathai, C.; Nguyen, T.D.; et al. Genesis of a highly pathogenic and potentially pandemic H5N1 influenza virus in eastern Asia. Nature 2004, 430, 209-213.

67. Luk, G.S.; Leung, C.Y.; Sia, S.F.; Choy, K.T.; Zhou, J.; Ho, C.C.; Cheung, P.P.; Lee, E.F.; Wai, C.K.; Li, P.C.; et al. Transmission of H7N9 Influenza Viruses with a Polymorphism at PB2 Residue 627 in Chickens and Ferrets. J Viro/ 2015, 89, 9939-9951, doi:10.1128/JVI.01444-15.

68. Hossain, M.J.; Hickman, D.; Perez, D.R. Evidence of expanded host range and mammalianassociated genetic changes in a duck H9N2 influenza virus following adaptation in quail and chickens. PLoS One 2008, 3, e3170, doi:10.1371/journal.pone.0003170.

69. Xiao, C.; Ma, W.; Sun, N.; Huang, L.; Li, Y.; Zeng, Z.; Wen, Y.; Zhang, Z.; Li, H.; Li, Q.; et al. PB2-588 V promotes the mammalian adaptation of H10N8, H7N9 and H9N2 avian influenza viruses. Sci Rep 2016, 6, 19474, doi:10.1038/srep19474.

70. Herfst, S.; Schrauwen, E.J.; Linster, M.; Chutinimitkul, S.; de Wit, E.; Munster, V.J.; Sorrell, E.M.; Bestebroer, T.M.; Burke, D.F.; Smith, D.J.; et al. Airborne transmission of influenza A/H5N1 virus between ferrets. Science 2012, 336, 1534-1541, doi:10.1126/science.1213362.

71. Xu, G.; Zhang, X.; Gao, W.; Wang, C.; Wang, J.; Sun, H.; Sun, Y.; Guo, L.; Zhang, R.; Chang, K.C.; et al. Prevailing PA Mutation K356R in Avian Influenza H9N2 Virus Increases Mammalian Replication and Pathogenicity. J Virol 2016, 90, 8105-8114, doi:10.1128/JVI.00883-16.

72. WHO. Avian Influenza Weekly Update number 788 (Accessed on April 16th, 2021). 2021.

73. Potdar, V.; Hinge, D.; Satav, A.; Simoes, E.A.F.; Yadav, P.D.; Chadha, M.S. Laboratory-Confirmed Avian Influenza A(H9N2) Virus Infection, India, 2019. Emerg Infect Dis 2019, 25, 2328-2330, doi:10.3201/eid2512.190636.

74. Lin, Y.P.; Shaw, M.; Gregory, V.; Cameron, K.; Lim, W.; Klimov, A.; Subbarao, K.; Guan, Y.; Krauss, S.; Shortridge, K.; et al. Avian-to-human transmission of H9N2 subtype influenza A viruses: relationship between H9N2 and H5N1 human isolates. Proc Natl Acad Sci U S A 2000, 97, 9654-9658, doi:10.1073/pnas.160270697.

75. Pawar, S.D.; Tandale, B.V.; Raut, C.G.; Parkhi, S.S.; Barde, T.D.; Gurav, Y.K.; Kode, S.S.; Mishra, A.C. Avian influenza H9N2 seroprevalence among poultry workers in Pune, India, 2010. PLoS One 2012, 7, e36374, doi:10.1371/journal.pone.0036374. 
76. Pan, Y.; Cui, S.; Sun, Y.; Zhang, X.; Ma, C.; Shi, W.; Peng, X.; Lu, G.; Zhang, D.; Liu, Y.; et al. Human infection with H9N2 avian influenza in northern China. Clin Microbiol Infect 2018, 24, 321-323, doi:10.1016/j.cmi.2017.10.026.

77. Chaudhry, M.; Webby, R.; Swayne, D.; Rashid, H.B.; DeBeauchamp, J.; Killmaster, L.; Criado, M.F.; Lee, D.H.; Webb, A.; Yousaf, S.; et al. Avian influenza at animal-human interface: One-health challenge in live poultry retail stalls of Chakwal, Pakistan. Influenza Other Respir Viruses 2020, 14, 257-265, doi:10.1111/irv.12718.

78. Blair, P.J.; Putnam, S.D.; Krueger, W.S.; Chum, C.; Wierzba, T.F.; Heil, G.L.; Yasuda, C.Y.; Williams, M.; Kasper, M.R.; Friary, J.A.; et al. Evidence for avian H9N2 influenza virus infections among rural villagers in Cambodia. J Infect Public Health 2013, 6, 69-79, doi:10.1016/j.jiph.2012.11.005.

79. Hoa, L.N.M.; Tuan, N.A.; My, P.H.; Huong, T.T.K.; Chi, N.T.Y.; Hau Thu, T.T.; Carrique-Mas, J.; Duong, M.T.; Tho, N.D.; Hoang, N.D.; et al. Assessing evidence for avian-to-human transmission of influenza A/H9N2 virus in rural farming communities in northern Vietnam. J Gen Virol 2017, 98, 2011-2016, doi:10.1099/jgv.0.000877.

80. Tahir, M.F.; Abbas, M.A.; Ghafoor, T.; Dil, S.; Shahid, M.A.; Bullo, M.M.H.; Ain, Q.U.; Abbas Ranjha, M.; Khan, M.A.; Naseem, M.T. Seroprevalence and risk factors of avian influenza H9 virus among poultry professionals in Rawalpindi, Pakistan. J Infect Public Health 2020, 13, 414-417, doi:10.1016/j.jiph.2020.02.030.

81. Quan, C.; Wang, Q.; Zhang, J.; Zhao, M.; Dai, Q.; Huang, T.; Zhang, Z.; Mao, S.; Nie, Y.; Liu, J.; et al. Avian Influenza A Viruses among Occupationally Exposed Populations, China, 2014-2016. Emerg Infect Dis 2019, 25, 2215-2225, doi:10.3201/eid2512.190261.

82. Ma, C.; Cui, S.; Sun, Y.; Zhao, J.; Zhang, D.; Zhang, L.; Zhang, Y.; Pan, Y.; Wu, S.; Duan, W.; et al. Avian influenza $A(H 9 N 2)$ virus infections among poultry workers, swine workers, and the general population in Beijing, China, 2013-2016: A serological cohort study. Influenza Other Respir Viruses 2019, 13, 415-425, doi:10.1111/irv.12641.

83. Heidari, A.; Mancin, M.; Nili, H.; Pourghanbari, G.H.; Lankarani, K.B.; Leardini, S.; Cattoli, G.; Monne, I.; Piccirillo, A. Serological evidence of H9N2 avian influenza virus exposure among poultry workers from Fars province of Iran. Virol J 2016, 13, 16, doi:10.1186/s12985-016-0472-z.

84. Wang, J.; Wu, M.; Hong, W.; Fan, X.; Chen, R.; Zheng, Z.; Zeng, Y.; Huang, R.; Zhang, Y.; Lam, T.T.; et al. Infectivity and Transmissibility of Avian H9N2 Influenza Viruses in Pigs. J Virol 2016, 90, 35063514, doi:10.1128/JVI.02605-15.

85. Yuan, Z.; Zhu, W.; Chen, Y.; Zhou, P.; Cao, Z.; Xie, J.; Zhang, C.; Ke, C.; Qi, W.; Su, S.; et al. Serological surveillance of $\mathrm{H} 5$ and $\mathrm{H} 9$ avian influenza A viral infections among pigs in Southern China. Microb Pathog 2013, 64, 39-42, doi:10.1016/j.micpath.2013.08.001.

86. Ninomiya, A.; Takada, A.; Okazaki, K.; Shortridge, K.F.; Kida, H. Seroepidemiological evidence of avian $\mathrm{H} 4, \mathrm{H} 5$, and $\mathrm{H} 9$ influenza A virus transmission to pigs in southeastern China. Vet Microbiol 2002, 88, 107-114, doi:10.1016/s0378-1135(02)00105-0.

87. Yong-Feng, Z.; Fei-Fei, D.; Jia-Yu, Y.; Feng-Xia, Z.; Chang-Qing, J.; Jian-Li, W.; Shou-Yu, G.; Kai, C.; Chuan-Yi, L.; Xue-Hua, W.; et al. Intraspecies and interspecies transmission of mink H9N2 influenza virus. Sci Rep 2017, 7, 7429, doi:10.1038/s41598-017-07879-1.

88. Kuiken, T.; Holmes, E.C.; McCauley, J.; Rimmelzwaan, G.F.; Williams, C.S.; Grenfell, B.T. Host species barriers to influenza virus infections. Science 2006, 312, 394-397, doi:10.1126/science.1122818. 
89. Nguyen, T.Q.; Rollon, R.; Choi, Y.K. Animal Models for Influenza Research: Strengths and Weaknesses. Viruses 2021, 13, doi:10.3390/v13061011.

90. Maher, J.A.; DeStefano, J. The ferret: an animal model to study influenza virus. Lab animal 2004, 33, 50-53, doi:10.1038/laban1004-50.

91. Chan, R.W.Y.; Chan, L.L.Y.; Mok, C.K.P.; Lai, J.; Tao, K.P.; Obadan, A.; Chan, M.C.W.; Perez, D.R.; Peiris, J.S.M.; Nicholls, J.M. Replication of H9 influenza viruses in the human ex vivo respiratory tract, and the influence of neuraminidase on virus release. Sci Rep 2017, 7, 6208, doi:10.1038/s41598-017-05853-5.

92. Perez, D.R.; Sorrell, E.; Angel, M.; Ye, J.; Hickman, D.; Pena, L.; Ramirez-Nieto, G.; Kimble, B.; Araya, Y. Fitness of Pandemic H1N1 and Seasonal influenza A viruses during Co-infection: Evidence of competitive advantage of pandemic H1N1 influenza versus seasonal influenza. PLoS Curr 2009, 1, RRN1011, doi:10.1371/currents.RRN1011.

93. Munster, V.J.; de Wit, E.; van den Brand, J.M.; Herfst, S.; Schrauwen, E.J.; Bestebroer, T.M.; van de Vijver, D.; Boucher, C.A.; Koopmans, M.; Rimmelzwaan, G.F.; et al. Pathogenesis and transmission of swine-origin $2009 \mathrm{~A}(\mathrm{H} 1 \mathrm{~N} 1)$ influenza virus in ferrets. Science 2009, 325, 481-483, doi:10.1126/science.1177127.

94. Sorrell, E.M.; Wan, H.; Araya, Y.; Song, H.; Perez, D.R. Minimal molecular constraints for respiratory droplet transmission of an avian-human H9N2 influenza A virus. Proc Natl Acad Sci U S A 2009, 106, 7565-7570, doi:10.1073/pnas.0900877106.

95. Kimble, J.B.; Sorrell, E.; Shao, H.; Martin, P.L.; Perez, D.R. Compatibility of H9N2 avian influenza surface genes and 2009 pandemic H1N1 internal genes for transmission in the ferret model. Proc Natl Acad Sci U S A 2011, 108, 12084-12088, doi:10.1073/pnas.1108058108.

96. Zell, R.; Groth, M.; Krumbholz, A.; Lange, J.; Philipps, A.; Dürrwald, R. Novel reassortant swine H3N2 influenza A viruses in Germany. Sci. Rep. 2020, 10, 14296, doi:10.1038/s41598-020-71275-5.

97. Ryt-Hansen, P.; Krog, J.S.; Østergaard Breum, S.; Hjulsager, C.K.; Pedersen, A.G.; Trebbien, R.; Larsen, L.E. Co-circulation of multiple influenza $A$ variants in swine harboring genes from seasonal human and swine influenza viruses. bioRxiv 2020, 2020.2007.2028.225706, doi:10.1101/2020.07.28.225706.

98. Everett, H.E.; Nash, B.; Londt, B.Z.; Kelly, M.D.; Coward, V.; Nunez, A.; van Diemen, P.M.; Brown, I.H.; Brookes, S.M. Interspecies Transmission of Reassortant Swine Influenza A Virus Containing Genes from Swine Influenza A(H1N1)pdm09 and A(H1N2) Viruses. Emerg. Infect. Dis. 2020, 26, 273281, doi:10.3201/eid2602.190486.

99. Powell, J.D.; Abente, E.J.; Chang, J.; Souza, C.K.; Rajao, D.S.; Anderson, T.K.; Zeller, M.A.; Gauger, P.C.; Lewis, N.S.; Vincent, A.L. Characterization of contemporary 2010.1 H3N2 swine influenza A viruses circulating in United States pigs. Virology 2021, 553, 94-101, doi:10.1016/j.virol.2020.11.006.

100. Obadan, A.O.; Kimble, B.J.; Rajao, D.; Lager, K.; Santos, J.J.S.; Vincent, A.; Perez, D.R. Replication and transmission of mammalian-adapted H9 subtype influenza virus in pigs and quail. J Gen Virol 2015, 96, 2511-2521, doi:10.1099/vir.0.000190.

101. Kimble, J.B.; Angel, M.; Wan, H.; Sutton, T.C.; Finch, C.; Perez, D.R. Alternative reassortment events leading to transmissible H9N1 influenza viruses in the ferret model. J. Virol. 2014, 88, 66-71, doi:10.1128/jvi.02677-13. 
102. Mok, C.K.; Yen, H.L.; Yu, M.Y.; Yuen, K.M.; Sia, S.F.; Chan, M.C.; Qin, G.; Tu, W.W.; Peiris, J.S. Amino acid residues 253 and 591 of the PB2 protein of avian influenza virus A H9N2 contribute to mammalian pathogenesis. J Virol 2011, 85, 9641-9645, doi:10.1128/JVI.00702-11.

103. Forbes, N.E.; Ping, J.; Dankar, S.K.; Jia, J.J.; Selman, M.; Keleta, L.; Zhou, Y.; Brown, E.G. Multifunctional adaptive NS1 mutations are selected upon human influenza virus evolution in the mouse. PLoS One 2012, 7, e31839, doi:10.1371/journal.pone.0031839.

104. Ping, J.; Keleta, L.; Forbes, N.E.; Dankar, S.; Stecho, W.; Tyler, S.; Zhou, Y.; Babiuk, L.; Weingartl, H.; Halpin, R.A.; et al. Genomic and protein structural maps of adaptive evolution of human influenza $A$ virus to increased virulence in the mouse. PLoS One 2011, 6, e21740, doi:10.1371/journal.pone.0021740.

105. Clements, A.L.; Sealy, J.E.; Peacock, T.P.; Sadeyen, J.R.; Hussain, S.; Lycett, S.J.; Shelton, H.; Digard, P.; Iqbal, M. Contribution of Segment 3 to the Acquisition of Virulence in Contemporary H9N2 Avian Influenza Viruses. J Virol 2020, 94, doi:10.1128/JVI.01173-20.

106. Zhang, J.; Su, R.; Jian, X.; An, H.; Jiang, R.; Mok, C.K.P. The D253N Mutation in the Polymerase Basic 2 Gene in Avian Influenza (H9N2) Virus Contributes to the Pathogenesis of the Virus in Mammalian Hosts. Virol Sin 2018, 33, 531-537, doi:10.1007/s12250-018-0072-8.

107. Lina, L.; Saijuan, C.; Chengyu, W.; Yuefeng, L.; Shishan, D.; Ligong, C.; Kangkang, G.; Zhendong, G.; Jiakai, L.; Jianhui, Z.; et al. Adaptive amino acid substitutions enable transmission of an H9N2 avian influenza virus in guinea pigs. Sci Rep 2019, 9, 19734, doi:10.1038/s41598-019-56122-6.

108. Qiao, C.; Liu, Q.; Bawa, B.; Shen, H.; Qi, W.; Chen, Y.; Mok, C.K.P.; Garcia-Sastre, A.; Richt, J.A.; Ma, W. Pathogenicity and transmissibility of reassortant $\mathrm{H} 9$ influenza viruses with genes from pandemic H1N1 virus. J Gen Virol 2012, 93, 2337-2345, doi:10.1099/vir.0.044040-0.

109. Mancera Gracia, J.C.; Van den Hoecke, S.; Richt, J.A.; Ma, W.; Saelens, X.; Van Reeth, K. A reassortant H9N2 influenza virus containing 2009 pandemic H1N1 internal-protein genes acquired enhanced pig-to-pig transmission after serial passages in swine. Sci Rep 2017, 7, 1323, doi:10.1038/s41598-017-01512-x.

110. Lv, J.; Wei, B.; Yang, Y.; Yao, M.; Cai, Y.; Gao, Y.; Xia, X.; Zhao, X.; Liu, Z.; Li, X.; et al. Experimental transmission in guinea pigs of H9N2 avian influenza viruses from indoor air of chicken houses. Virus Res 2012, 170, 102-108, doi:10.1016/j.virusres.2012.09.003.

111. Sang, X.; Wang, A.; Ding, J.; Kong, H.; Gao, X.; Li, L.; Chai, T.; Li, Y.; Zhang, K.; Wang, C.; et al. Adaptation of H9N2 AIV in guinea pigs enables efficient transmission by direct contact and inefficient transmission by respiratory droplets. Sci Rep 2015, 5, 15928, doi:10.1038/srep15928.

112. He, L.; Wu, Q.; Jiang, K.; Duan, Z.; Liu, J.; Xu, H.; Cui, Z.; Gu, M.; Wang, X.; Liu, X.; et al. Differences in transmissibility and pathogenicity of reassortants between $\mathrm{H} 9 \mathrm{~N} 2$ and 2009 pandemic H1N1 influenza A viruses from humans and swine. Arch Virol 2014, 159, 1743-1754, doi:10.1007/s00705014-2009-3.

113. Hao, M.; Han, S.; Meng, D.; Li, R.; Lin, J.; Wang, M.; Zhou, T.; Chai, T. The PA Subunit of the Influenza Virus Polymerase Complex Affects Replication and Airborne Transmission of the H9N2 Subtype Avian Influenza Virus. Viruses 2019, 11, doi:10.3390/v11010040.

114. Liu, K.; Wang, X.; Jiang, D.; Xu, N.; Gao, R.; Han, W.; Gu, M.; Hu, J.; Liu, X.; Hu, S.; et al. Pathogenicity and transmissibility of an $\mathrm{H} 9 \mathrm{~N} 2$ avian influenza virus that naturally harbors the mammalianadaptive molecular factors in the hemagglutinin and PB2 proteins. J Infect 2021, 82, e22-e23, doi:10.1016/j.jinf.2020.09.009. 
115. Zhang, X.; Li, Y.; Jin, S.; Wang, T.; Sun, W.; Zhang, Y.; Li, F.; Zhao, M.; Sun, L.; Hu, X.; et al. H9N2 influenza virus spillover into wild birds from poultry in China bind to human-type receptors and transmit in mammals via respiratory droplets. Transbound Emerg Dis 2021, doi:10.1111/tbed.14033.

116. Group, S.H.W. Assessing the fitness of distinct clades of influenza A (H9N2) viruses. Emerg Microbes Infect 2013, 2, e75, doi:10.1038/emi.2013.75.

117. Zhang, K.; Zhang, Z.; Yu, Z.; Li, L.; Cheng, K.; Wang, T.; Huang, G.; Yang, S.; Zhao, Y.; Feng, N.; et al. Domestic cats and dogs are susceptible to H9N2 avian influenza virus. Virus Res 2013, 175, 52-57, doi:10.1016/j.virusres.2013.04.004.

118. Chin, A.W.H.; Yen, H.L.; Krauss, S.; Webby, R.J.; Poon, L.L.M. Recombinant influenza virus with a pandemic $\mathrm{H} 2 \mathrm{~N} 2$ polymerase complex has a higher adaptive potential than one with seasonal H2N2 polymerase complex. J Gen Virol 2016, 97, 611-619, doi:10.1099/jgv.0.000385.

119. Yang, J.; Yan, R.; Roy, A.; Xu, D.; Poisson, J.; Zhang, Y. The I-TASSER Suite: protein structure and function prediction. Nat. Methods 2015, 12, 7-8, doi:10.1038/nmeth.3213. 